\title{
Spatial association between outdoor air pollution and lung cancer incidence in China
}

\author{
D. F. Xing ${ }^{1,2 \dagger}$, C. D. Xu ${ }^{1 *}{ }^{*}$, X. Y. Liao ${ }^{3 *}$, T. Y. Xing ${ }^{2}$, S. P. Cheng ${ }^{4}$, M. G. Hu ${ }^{1}$ and J. X. Wang ${ }^{1}$
}

\begin{abstract}
Background: Lung cancer is the most common cancer in China. Previous studies have indicated that lung cancer incidence exhibits remarkable spatial heterogeneity, and lung cancer is related to outdoor air pollution. However, the non-linear spatial association between outdoor air pollution and lung cancer incidence in China remains unclear.
\end{abstract}

Methods: In this study, the relationships between the lung cancer incidence of males and females from 207 counties in China in 2013 with annual concentrations of PM2.5, PM10, SO $, \mathrm{NO}_{2}, \mathrm{CO}$ and $\mathrm{O}_{3}$ were analysed. GeoDetector q statistic was used for examining the non-linear spatial association between outdoor air pollution and incidence of lung cancer.

Results: An apparent spatial and population gender heterogeneity was found in the spatial association between outdoor air pollution and lung cancer incidence. Among the six selected pollutants, $\mathrm{SO}_{2}$ has the greatest influence on lung cancer ( $q=0.154$ in females) in north China. In the south, each selected pollutant has a significant impact on males or females, and the mean q value in the south is 0.181 , which is bigger than that in the north $(q=0.154)$. In addition, the pollutants have evident non-linear interaction effects on lung cancer. In north China, the interaction between $\mathrm{SO}_{2}$ and PM2.5 is the dominant interaction, with q values of 0.207 in males and 0.334 in females. In the south, the dominant interactive factors are between $\mathrm{SO}_{2}$ and $\mathrm{O}_{3}$ in males and between $\mathrm{SO}_{2}$ and $\mathrm{CO}$ in females, with q values of $0.45,0.232$ respectively. Smoking is a substantial contributor to lung cancer among men, either in South or North China, with q value of 0.143 and 0.129 respectively, and the interaction between smoking and air pollutants increases this risk.

Conclusions: This study implies that the influence of $\mathrm{SO}_{2}$ and PM2.5 on lung cancer should be focused on in north China, and in the south, the impact of $\mathrm{O}_{3}$ and $\mathrm{CO}$ as well as their interaction with $\mathrm{SO}_{2}$ need to be paid more attention. Smoking, particularly in men, remains a significant risk factor for lung cancer in both North and South China.

Keywords: Lung cancer, Outdoor air pollution, GeoDetector, Spatial association, Smoking

\footnotetext{
*Correspondence: xucd@|reis.ac.cn; liaoxy@igsnrr.ac.cn

${ }^{\dagger}$ D. F. Xing and C. D. Xu contributed equally to this work.

${ }^{1}$ State Key Laboratory of Resources and Environmental Information System,

Institute of Geographic Sciences and Natural Resources Research, Chinese

Academy of Sciences, Beijing, China

${ }^{3}$ Key Laboratory of Land Surface Pattern and Simulation, Beijing Key

Laboratory of Environmental Damage Assessment and Remediation, Institute

of Geographic Sciences and Natural Resources Research, Chinese Academy

of Science (CAS), Beijing 100101, China

Full list of author information is available at the end of the article
}

(C) The Author(s). 2019 Open Access This article is distributed under the terms of the Creative Commons Attribution 4.0 International License (http://creativecommons.org/licenses/by/4.0/), which permits unrestricted use, distribution, and reproduction in any medium, provided you give appropriate credit to the original author(s) and the source, provide a link to the Creative Commons license, and indicate if changes were made. The Creative Commons Public Domain Dedication waiver (http://creativecommons.org/publicdomain/zero/1.0/) applies to the data made available in this article, unless otherwise stated. 


\section{Background}

Lung cancer is one of the most serious malignancies which threaten human life; as the leading cause of cancer deaths worldwide, it accounts for about $26 \%$ of all cancers and is ranked as the deadliest cancer among males and the second deadliest cancer among females $[1,2]$. Despite the overall 5-year survival rate for lung cancer has slightly improvement over time, it still remains poor, only with $16.8 \%$ in 2004 [3].

The incidence of lung cancer in China is at a high level relative to that in the rest of the world, and it is also the highest incidence of malignant tumours in China [4]. According to the Third National Causes of Death Sampling Survey (2004-2005) of China, the mortality of lung cancer increased significantly from 5.47/ $10^{5}$ in the 1970 s to $30.83 / 10^{5}$ in 2004-2005 [5], and in the next few years, lung cancer mortality remained high [6]. The severity of China's lung cancer problem results in a considerable economic burden every year. From 1996 to 2011, the direct medical expenses for lung cancer cases amounted to $\$ 1517-\$ 4018$, with an average annual growth rate of $2.2 \%$ [7].

Previous studies have shown that smoking status, family history and other factors (e.g. indoor air pollution, radon exposure) have significant effects on lung cancer $[3,8]$. As one of the leading risk factors for cancer, smoking contributes a large proportion of the lung cancer burden, especially among men. One comparative risk assessment conducted in mainland China indicated that the population-attributable fractions of lung cancer for smoking in men is approximately $55.1 \%$, about five times that of women [9].

Recently, an increasing number of studies have reported positive associations between risk of lung cancer and outdoor air pollution $[10,11]$. Since the 1990s, outdoor air pollution has been a top environmental problem in China, accompanied by the rapid development of industry and urbanisation [12]. In 2000, the concentrations of air pollutants in more than half the country's cities were over Chinese Grade II standards (hazardous to health; highest level is Grade VI). Severe air pollution problems pose a great threat to health [13]. In China, the mortality attributed to air pollution is higher than that linked to alcohol and drug use and ranks as the fourth cause of death [14].

Evidence of the association between exposure to outdoor air pollution and lung cancer continues to accumulate [15-17], but the understanding of which pollutants control or influence the incidence (or mortality) and its spatial variation remains an unsolved problem. Inhalable airborne particles (PM2.5, PM10) have a statistical association with lung cancer [18], and each $10 \mu \mathrm{g} / \mathrm{m}^{3}$ increase in PM2.5 concentration is correlated with a $15-27 \%$ increase in lung cancer mortality [19]. Meanwhile, gaseous pollutants, such as sulphur dioxide $\left(\mathrm{SO}_{2}\right)$, ozone $\left(\mathrm{O}_{3}\right)$, carbon monoxide $(\mathrm{CO})$, and nitrogen dioxide $\left(\mathrm{NO}_{2}\right)$ have also been examined for potential relationships with lung cancer [20-22]. However, results from previous studies are sometimes inconsistent, an important cause may be the fundamental regional spatial association between various pollutants and lung cancer.

China covers a vast territory, and its northern and southern regions present an obvious spatial heterogeneity in climatic conditions, economic and industry structure. Their air pollutants also have apparent regional characteristics. For example, the concentrations of PM2.5, PM10, $\mathrm{SO}_{2}$ and $\mathrm{CO}$ in north China are significantly higher than those in south China [23, 24].

In this study, GeoDetector [25] was used to quantitatively assessing the determinant power of principle air pollutants and smoking on lung cancer, analysing the interaction of these factors in North and South China. Their various influences and associations with lung cancer in these regions were then analysed and discussed.

\section{Methods \\ Study area}

China, which has high lung cancer burden in the world, is the largest developing country located in the eastern part of Asia and the west coast of the Pacific Ocean $\left(3^{\circ} 52^{\prime}-53^{\circ} 33^{\prime} \mathrm{N}, 73^{\circ} 30^{\prime}-135^{\circ} 3^{\prime} \mathrm{E}\right)$. It was divided into the north and the south regions using a prominent geographical boundary created by the Qinling Mountains and the Huai River line. Apparent differences of climate characteristics, economic and industry structure exists in the north and the south regions. For example, north China is dominated by temperate continental climate, it has long and dry winter, while the south China was dominated by subtropical monsoon climate, it has higher temperature and more abundant precipitation. The heavy industries hold the important position in the north for it has the abundant energy resources (eg, coal, petroleum), while the south pays more attention to the development of light industry.

\section{Data of lung cancer}

The female and male lung cancer incidence data in 2013 in 207 counties of China were obtained from the Annual Report of Cancer Registration in China 2016 [26] (Fig. 1). The data has been evaluated for integrity and reliability in accordance with the Guidelines for Cancer Registration in China, and has been released as official data by the National Cancer Centre. The dataset covered 255 cities and counties from all 31 provinces in mainland China, with a total survey population of 227 million, accounting for about $20 \%$ of the country's total population. After geocoding each county, 207 were matched in the county map. 


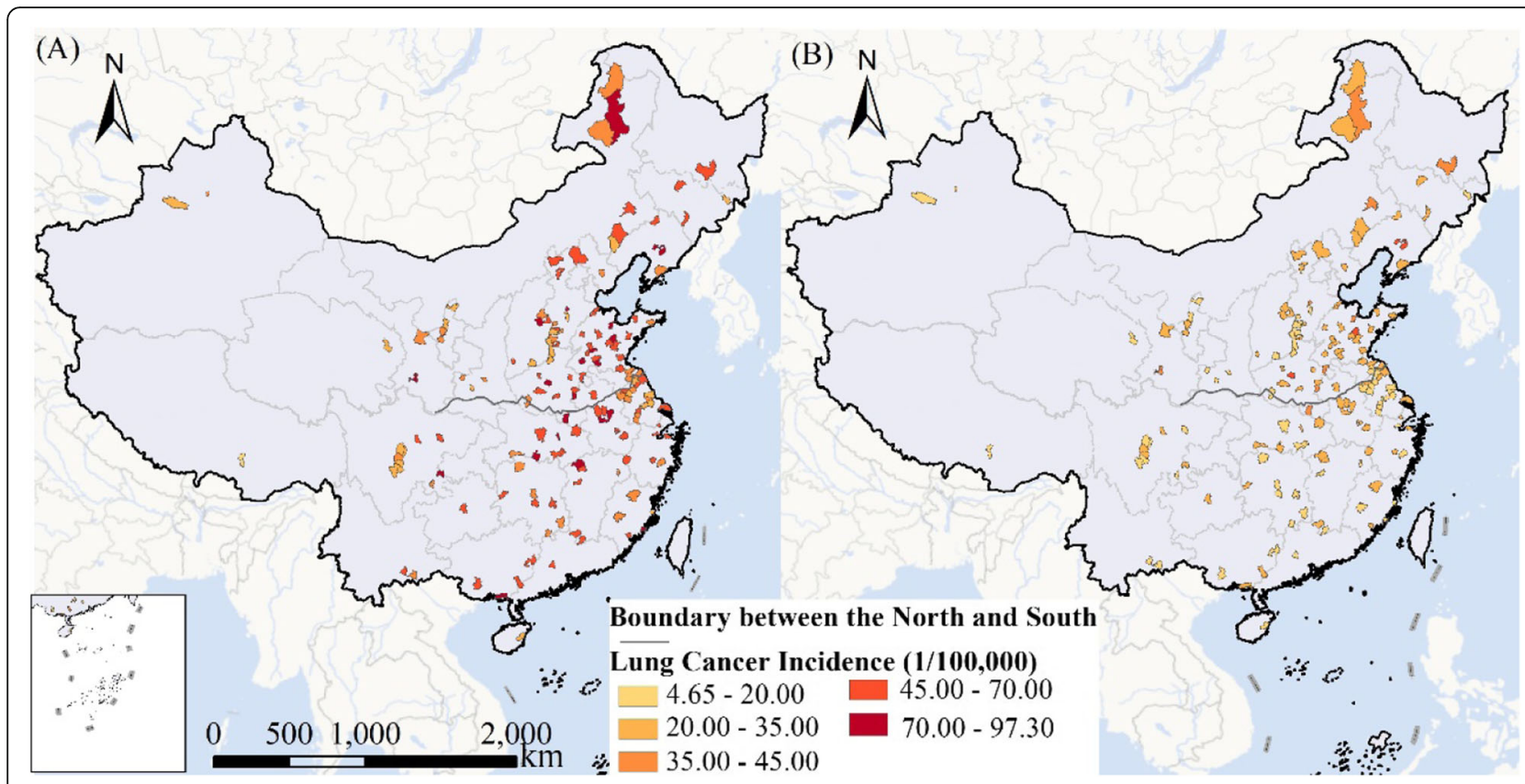

Fig. 1 Lung cancer incidence in (A) males and (B) females in 207 counties of China in 2013

The incidence of lung cancer was adjusted by age structure.

There are apparent climatic, industry structure and socio-economic differences on either side of the Qinling Mountains and the Huai River, which serves as the boundary between north and south China [27]. These 207 counties distributed in 31 provinces of China, among them, 102 are located in north China and 105 are located in south China. In north China, the total incidence of lung cancer is $38.91 / 10^{5}$, the lung cancer incidence among males and females are $51.69 / 10^{5}$ and $26.13 / 10^{5}$ respectively. In south China, the total incidence of lung cancer is $35.51 / 10^{5}$, the lung cancer incidence among males and females are $51.53 / 10^{5}$ and $19.48 / 10^{5}$ respectively (Table 1 ). In this study, the spatial pattern of lung cancer incidences in north and south China as well as in different genders were analysed.

\section{Air pollution data}

Previous studies have indicated that the air pollution index, e.g. PM2.5, PM10, $\mathrm{SO}_{2}, \mathrm{O}_{3}, \mathrm{CO}$, and $\mathrm{NO}_{2}$ has an

Table 1 Statistical information for lung cancer incidence in different genders in north and south China

\begin{tabular}{lllll}
\hline $\begin{array}{l}\text { Lung cancer Incidence } \\
(1 / 100,000)\end{array}$ & Max & Min & Mean & $\begin{array}{l}\text { Standard } \\
\text { deviation }\end{array}$ \\
\hline Males in north China & 118.27 & 20.50 & 51.69 & 17.10 \\
Females in north China & 66.93 & 11.63 & 26.13 & 9.96 \\
Males in south China & 97.3 & 4.65 & 51.53 & 16.53 \\
Females in south China & 36.6 & 0.00 & 19.48 & 6.29 \\
\hline
\end{tabular}

important effect on lung cancer in China [28]. Epidemiological studies have shown that air pollutants, such as PM2.5, PM10 and $\mathrm{O}_{3}$, contribute to oxidative stress in the pulmonary system, thus potentially increasing the production of mediators of pulmonary inflammation and initiating or promoting mechanisms of carcinogenesis [29]. In the current study, data about these factors were collected for an analysis of their contribution to the spatial variation of lung cancer.

The China National Environmental Monitoring Centre published air pollution data for mainland China in May 2014, recording a concentration of six air pollutantsPM2.5, PM10, $\mathrm{SO}_{2}, \mathrm{O}_{3}, \mathrm{CO}$, and $\mathrm{NO}_{2}$-every hour throughout 936 national monitoring stations, which were examined by quality assurance procedures. In this study, the annual average concentration of each of these six lung cancer pollutants from May 2014 to May 2015 was calculated and analysed (Table 2). Regressionkriging was used to interpolate the air pollution of these 207 counties based on air pollution data from the 936 monitoring stations.

\section{Fine particulate (PM2.5)}

The impact of fine particulate matter (PM2.5) on lung cancer has been widely discussed in many previous studies [30]. A number of researchers have found that PM2.5 is positively correlated with the incidence of lung cancer [31]. Following previous work, the present research used PM2.5 to assess the risk of lung cancer incidence.

In general, the average concentration of PM2.5 in the north $\left(70.51 \mu \mathrm{g} / \mathrm{m}^{3}\right)$ is higher than that in the south 
Table 2 Statistical information for each annual pollutant

\begin{tabular}{|c|c|c|c|c|c|}
\hline Factor & Abbreviation & Max & Min & Mean & $\begin{array}{l}\text { Standard } \\
\text { deviation }\end{array}$ \\
\hline $\begin{array}{l}\text { Fine particulate } \\
\left(\mu \mathrm{g} / \mathrm{m}^{3}\right)\end{array}$ & PM2.5 & 139.22 & 14.40 & 64.18 & 21.05 \\
\hline $\begin{array}{l}\text { Inhalable particles } \\
\left(\mu \mathrm{g} / \mathrm{m}^{3}\right)\end{array}$ & PM10 & 235.32 & 37.46 & 110.87 & 37.67 \\
\hline $\begin{array}{l}\text { Sulfur dioxide } \\
\left(\mu \mathrm{g} / \mathrm{m}^{3}\right)\end{array}$ & $\mathrm{SO}_{2}$ & 192.71 & 1.92 & 35.54 & 25.05 \\
\hline Ozone $\left(\mu \mathrm{g} / \mathrm{m}^{3}\right)$ & $\mathrm{O}_{3}$ & 98.44 & 0.00 & 50.66 & 15.08 \\
\hline $\begin{array}{l}\text { Carbon monoxide } \\
\left(\mathrm{mg} / \mathrm{m}^{3}\right)\end{array}$ & $\mathrm{CO}$ & 3.27 & 0.41 & 1.26 & 0.46 \\
\hline $\begin{array}{l}\text { Nitrogen dioxide } \\
\left(\mu \mathrm{g} / \mathrm{m}^{3}\right)\end{array}$ & $\mathrm{NO}_{2}$ & 89.42 & 7.42 & 39.12 & 13.87 \\
\hline
\end{tabular}

Note: $\mu \mathrm{g} / \mathrm{m}^{3}: 1$ microgram per cubic meters; $\mathrm{mg} / \mathrm{m}^{3}: 1 \mathrm{mg}$ per cubic meters

$\left(57.86 \mu \mathrm{g} / \mathrm{m}^{3}\right)$. Among the 10 counties with the highest concentration of PM2.5 in the north, 6 of them are located in Hebei province, which is the typical province dominated by industry adjacent to Beijing in south China. The most polluted PM2.5 areas are the north China plain, following with the Sichuan basin.

\section{Inhalable particles (PM10)}

Compared with the association between PM2.5 and lung cancer, that between PM10 and lung cancer has been less studied. Most previous studies have stated that the correlation of PM10 with lung cancer is not as strong as that of PM2.5. Although a positive association between PM10 and lung cancer incidence has been found by some studies [30], it still requires further research.

The average concentration of PM10 in the north and south is $131.72 \mu \mathrm{g} / \mathrm{m}^{3}$ and $90.02 \mu \mathrm{g} / \mathrm{m}^{3}$, respectively. The spatial distribution of high concentration areas of PM10 is approximately the same as that of PM2.5. Counties in north China plain also took the important position with the average concentration of approximately $180 \mu \mathrm{g} / \mathrm{m}^{3}$. In the south China, the regions with high concentration of PM10 are in the southwest and eastern China.

\section{Sulfur dioxide $\left(\mathrm{SO}_{2}\right)$}

$\mathrm{SO} 2$, similar to PM, is a major pollutant in China. Given that they are both derived primarily from coal combustion, the effects of SO2 and PM are often considered together. Studies have shown that exposure to $\mathrm{SO}_{2}$ increases the risk of lung cancer, and it is estimated that a $1 \%$ increase in $\mathrm{SO}_{2}$ emissions can lead to 0.004 more deaths per 100,000 population due to lung cancer in China [32]. Therefore, analysing the impact of $\mathrm{SO}_{2}$ on different regions of China is of significance.

As a product of coal combustion, the average concentration of $\mathrm{SO}_{2}$ in studied counties in the north $\left(50.56 \mu \mathrm{g} / \mathrm{m}^{3}\right)$ is significantly higher than that in the south $\left(20.50 \mu \mathrm{g} / \mathrm{m}^{3}\right)$. This is consistent with the energy structures in these two regions, in north China, the consumption of coal is higher than in south due to the long winter and industrial consumption. High concentration areas of $\mathrm{SO}_{2}$ are mainly located in the north China plain and northeast China, where the heavy industry based on coal-consuming is the dominant industry.

\section{Ozone $\left(\mathrm{O}_{3}\right)$}

The effect of $\mathrm{O}_{3}$ on lung cancer is varied in different studies. Most existing studies are concerned about the impact of $\mathrm{O}_{3}$ on lung cancer mortality rate. Some studies have found a strong negative correlation between $\mathrm{O}_{3}$ and lung cancer [33], whereas some found no evidence of such association [20,34]. The different results may be caused by variations in the study areas or methods.

Among the six studied pollutants, $\mathrm{O}_{3}$ is the only one whose concentration in the south is higher than that in the north, with $49.97 \mu \mathrm{g} / \mathrm{m}^{3}$ in north and $50.35 \mu \mathrm{g} / \mathrm{m}^{3}$ in south. The geographical distribution of $\mathrm{O}_{3}$ has strong spatial heterogeneity, it is mainly concentrated in Sichuan basin in southwest and eastern China, although the average concentration of $\mathrm{O}_{3}$ in the north is lower than that in the south, there are still high concentrations in regions near Beijing.

\section{Carbon monoxide (CO)}

Few studies have explored the association between $\mathrm{CO}$ and lung cancer in detail; most related studies analysed it with $\mathrm{NO}_{2}, \mathrm{SO}_{2}$ and other pollutants. Some works have found that similar to $\mathrm{NO}_{2}$ and $\mathrm{SO}_{2}, \mathrm{CO}$ is significantly associated with lung cancer incidence [35], whereas others found no association [36]. Thus, further studies are needed.

The average concentration of $\mathrm{CO}$ in total 102 studied counties in the north is $1.46 \mathrm{mg} / \mathrm{m}^{3}$, which is higher than that in the south $\left(1.05 \mathrm{mg} / \mathrm{m}^{3}\right)$. High concentrations of $\mathrm{CO}$ are in several provinces in the north China plain, while in the south, few areas have high concentrations of $\mathrm{CO}$.

\section{Nitrogen dioxide $\left(\mathrm{NO}_{2}\right)$}

There are many studies focusing on the association between $\mathrm{NO}_{2}$ and lung cancer, many of which have suggested that $\mathrm{NO}_{2}$ has an important impact on lung cancer [36, 37]. However, there remains inconsistencies about the role of $\mathrm{NO}_{2}$ in lung cancer incidence in men and women [35].

The average concentration of $\mathrm{NO}_{2}$ in total 102 studied counties in the north is $41.52 \mu \mathrm{g} / \mathrm{m}^{3}$, which is higher than that in the south $\left(36.72 \mu \mathrm{g} / \mathrm{m}^{3}\right)$. High concentrations of $\mathrm{NO}_{2}$ are mainly in regions near Beijing. 


\section{Smoking rate data}

The smoking rate dataset came from a serial crosssectional National Health Services Survey (NHSS) organized by the National Health Commission (NHC) of the People's Republic of China. Smoking status was surveyed of the entire population of 31 provinces, autonomous regions, and municipalities in mainland of China. In this smoking rate dataset, the proportion of current smokers in 2008 was $24.9 \%$. For men, prevalence was $48.4 \%$, while it was less than one-tenth of that $(2.3 \%)$ for women [38]. Therefore, it mainly represent the smoking status of males. In the current study, smoking rate data in study region was obtained using geostatistical-based downscaling method based on the dataset [39-41], and then was used to analyse its association with lung cancer in men and the effect of interaction with air pollutants.

\section{GeoDetector}

In this study, GeoDetector was used for assessing the influence of select air pollution factors on lung cancer incidence in north and south China. GeoDetector is a spatial variance analysis method that explains non-linear associations between potential factor and spatial phenomenon $[42,43]$. The method was first proposed for assessing the spatial association between neural tube defect occurrences and their risk factors [25], and it has since been widely applied to such areas as health, environment and geography $[44,45]$. In GeoDetector, factor detector and interaction detector are two commonly used functions.

In this study, the factor detector was used for detecting the spatial association between incidence of lung cancer and potential air pollution factors. To introduce the method briefly, we assume that $\mathrm{X}$ is a risk factor (e.g., PM2.5, $\mathrm{SO}_{2}, \mathrm{CO}$, etc), which was used to test the spatial association with lung cancer incidence. The core underlying assumption of the Geodetector q statistic is that, if $\mathrm{X}$ (explanatory variable) causes $\mathrm{Y}$ (explained variable), their spatial distribution will be consistent. In terms of this study, if the air pollutant (X) has an important influence on lung cancer rate $(\mathrm{Y})$, then the spatial distribution of $\mathrm{X}$ would be similar to that of lung cancer occurrence. The determinant power of $\mathrm{X}$ was quantified by the $\mathrm{q}$ statistic, where the range of $\mathrm{q}$ is the interval $[0,1]$. In the calculation process, $\mathrm{X}$ was first divided into several different strata, then the spatial association between $\mathrm{X}$ and $\mathrm{Y}$ was analyzed by comparing variances between the strata. The spatial correspondence between $X$ and incidence of lung cancer could be measured by the q statistic which is defined as.

$$
\mathrm{q}=1-\frac{\sum_{h=1}^{S} N_{h} \sigma_{h}^{2}}{N \sigma^{2}}=1-\frac{S S W}{S S T}
$$

$$
\begin{aligned}
& S S W=\sum_{h=1}^{S} N_{h} \sigma_{h}^{2} \\
& S S T=N \sigma^{2}
\end{aligned}
$$

where $h=1,2 \ldots, S$ is the strata of an air pollution factor; $N_{h}$ and $N$ present the numbers of counties in stratum $h$ and in the whole study counties, respectively; $\sigma_{h}^{2}$ and $\sigma^{2}$ denote the variances in lung cancer incidences in stratum $h$ and in the whole study area, respectively. SSW and SST are the variance of lung cancer incidence within strata $h$ of factor $\mathrm{X}$ and the global variance of lung cancer incidence in the whole study area, respectively. The $q$ value means that a factor explains $q \times 100 \%$ of the lung cancer incidence; the bigger the $q$ value, the larger the non-linear association with regard to the incidence of lung cancer. The range of $q$ is in the interval $[0,1]$. In the study, the south and the north China were divided into three spatial strata, respectively. The stratification was implemented based on the minimum within-strata variation and maximum between-strata variation constraint $[42,43]$.

Non-central F-distribution was used for the test of spatial association between two factors [42], which is defined as.

$$
\begin{aligned}
& \mathrm{P}(1<X)=\mathrm{P}\left(\mathrm{F}<\frac{N-S}{S-1} \frac{X}{1-X}\right)=1-\alpha \\
& \mathrm{X}=\frac{1}{\sigma^{2}}\left[\sum_{h=1}^{S} \bar{Y}_{h}^{2}-\frac{1}{N}\left(\sum_{h=1}^{S} \sqrt{N_{h}} Y_{h}\right)^{2}\right]
\end{aligned}
$$

where $\alpha$ is the probability of $\mathrm{q} \geq \chi \cdot \bar{Y}_{h}$ is the mean value of stratum $h$. The null hypothesis of the test is: there presents no spatial association between two factors and the alternative hypothesis is: there exists spatial association between them, respectively. Note that if spatial distribution of lung cancer incidence is completely driven by the factor $\mathrm{X}$, the within sum of variance is 0 and $\mathrm{q}=1$, while if $q=0$, it implies that lung cancer incidence and factor $\mathrm{X}$ have not any spatial association with each other.

The q statistic is a method of measuring the spatial association between two variables. In this study, the $\mathrm{q}$ statistic was not only used to measure the spatial relationship between air pollutants or smoking rate and lung cancer in factor detector but also to evaluate the effects on lung cancer of interactions between two factors.

Interaction detector was used for identifying the interaction effect between two factors on lung cancer. Interaction detector assess the interaction effect by comparing value of $\mathrm{q}(\mathrm{X} 1 \cap \mathrm{X} 2)$ with values of $\mathrm{q}(\mathrm{X} 1)$ and $q(X 2)$, in which $X 1 \cap X 2$ was implemented by overlaying the two variables using GIS. The method could determine the kind of interaction (non-linear weakening, 
univariate weakening, bivariate enhancement, independent, non-linear enhancement) existing between two air pollution factors acting together (Table 3). The GeoDetector can be freely downloaded from http://www.geode tector.cn/.

\section{Results}

\section{Spatial patterns}

In general, the incidence of lung cancer in males was apparently higher than that in females. In 2013, the mean incidences of male and female lung cancer were 51.61/ $10^{5}$ and $22.76 / 10^{5}$, respectively. The incidences of lung cancer in north and south China only slightly differed at $38.91 / 10^{5}$ and $35.51 / 10^{5}$, respectively (Fig. 1 ).

\section{Factor detector}

The results of the factor detector indicated spatial and population gender heterogeneities in the spatial association between outdoor air pollution and lung cancer incidence. In general, air pollution in south China had a greater impact on lung cancer than in the north, and males in the south were more likely to be affected by polluted air than were the females. Table 4 shows the results of the factor detector in north and south China.

In north China, among the six selected pollutants, $\mathrm{SO}_{2}$ was the dominant factor affecting the spatial distribution of lung cancer in the region, with a $\mathrm{q}$ value of 0.154 ( $p$ value $<0.05$ ) for the females.

In south China, PM2.5 and CO were found to be important factors that had a significant influence on lung cancer incidence in both sexes. For the males, $\mathrm{O}_{3}$ had the greatest explanatory power for lung cancer incidence, with a q value of $0.314 . \mathrm{SO}_{2}$ played a relatively weak role, with a q value of 0.140 . As for the females, results showed that CO, PM2.5 and PM10 had a significant influence on lung cancer incidence, with q values of $0.113,0.110$ and 0.101 ( $p$ values $<0.05$ ), respectively. Significant association between lung cancer and smoking rate was found among men, with q values of 0.143 and 0.129 in North China and South China, respectively.

Table 3 Interaction relationship between two factors

\begin{tabular}{ll}
\hline Description & Interaction \\
\hline$q(X 1 \cap X 2)<\operatorname{Min}(q(X 1), q(X 2))$ & Non-linear weakening \\
$\operatorname{Min}(q(X 1), q(X 2))<q(X 1 \cap X 2)$ & Univariate weakening \\
$<\operatorname{MaX}(q(X 1), q(X 2))$ & \\
$q(X 1 \cap X 2)>\operatorname{Max}(q(X 1), q(X 2))$ & Bivariate enhancement \\
$q(X 1 \cap X 2)=q(X 1)+q(X 2)$ & Independent \\
$q(X 1 \cap X 2)>q(X 1)+q(X 2)$ & Non-linear enhancement
\end{tabular}

Note: $\mathrm{q}(\mathrm{X} 1 \cap \mathrm{X} 2)$ represents the $\mathrm{q}$ value from the interaction relationship between pollutants $\mathrm{X} 1$ and $\mathrm{X} 2$

\section{Interaction detector}

The results of the interaction detector showed that the interaction between any two pollutants enhanced the risk of lung cancer (Fig. 2).

For the males in north China, the interaction between $\mathrm{SO}_{2}$ and PM2.5 had the highest q value of 0.207 , which is greater than the sum of the $q$ values of the two factors, showing a relationship of non-linear enhancement, which implies there presents effect modification for the cancer. This was followed by the interaction between $\mathrm{SO}_{2}$ and $\mathrm{O}_{3}$, which had a q value of 0.199 , and the interaction between PM2.5 and $\mathrm{O}_{3}$, which had a $\mathrm{q}$ value of 0.180 . The dominant interaction is between $\mathrm{SO}_{2}$ and PM2.5.

For the females in north China, the interaction between $\mathrm{SO}_{2}$ and PM2.5 also had effect modification, as the highest q value (0.334) and it is greater than the sum of the $q$ values of the two factors. This was followed by the interaction between $\mathrm{SO}_{2}$ and $\mathrm{CO}$, which presented a $q$ value of 0.326 , and the interaction between $\mathrm{SO}_{2}$ and $\mathrm{NO}_{2}$, which showed a q value of 0.319 . The interaction is between $\mathrm{SO}_{2}$ and PM2.5 also took the dominant role among the females in north China.

Among the males in south China, the interaction between $\mathrm{SO}_{2}$ and $\mathrm{O}_{3}$ had the highest $\mathrm{q}$ value of 0.45 , which is greater than the maximum q value among the two factors, indicating a relationship of bivariate enhancement. This was followed by the interaction between PM2.5 and $\mathrm{O}_{3}$, which had a q value of 0.431 , and the interaction between $\mathrm{O}_{3}$ and $\mathrm{CO}$, which had a $\mathrm{q}$ value of 0.421 . The dominant interaction is between $\mathrm{SO}_{2}$ and $\mathrm{O}_{3}$.

Among the females in south China, the interaction between $\mathrm{SO}_{2}$ and $\mathrm{CO}$ had the highest $\mathrm{q}$ value of 0.231 , which is greater than the sum of the q values of the two factors, implying there presents effect modification for the cancer. This was followed by the interaction between $\mathrm{SO}_{2}$ and $\mathrm{NO}_{2}$, which had a $\mathrm{q}$ value of 0.229 , and the interaction between PM2.5 and CO, which showed a $\mathrm{q}$ value of 0.221 . The dominant interaction is between $\mathrm{SO}_{2}$ and $\mathrm{CO}$.

Note that despite the dominant factor and interaction in north and south as well as in males and females are different, $\mathrm{SO}_{2}$ appears in all the dominant interactions, in other words, in all six selected pollutants, $\mathrm{SO}_{2}$ needs to be focused on no matter in south or north.

The effects of interaction between smoking and air pollutants in North and South China is shown in Fig. 3, indicating that $\mathrm{q}$ values of pollutants increased significantly after interacting with the smoking rate.

For males in North China, the interaction between smoking and $\mathrm{O}_{3}$ had the highest q value of 0.296 - much greater than the $\mathrm{q}$ value of $\mathrm{O}_{3}$ alone-followed by the interaction between smoking and $\mathrm{NO}_{2}$, which had a $\mathrm{q}$ value of 0.288 . The dominant interaction being between smoking and $\mathrm{O}_{3}$. 
Table $4 \mathrm{q}$ values for different air pollutant factors and smoking rates in north and south China

\begin{tabular}{llllllll}
\hline & $\mathrm{PM} 2.5$ & $\mathrm{PM} 10$ & $\mathrm{SO}_{2}$ & $\mathrm{NO}_{2}$ & $\mathrm{O}_{3}$ & $\mathrm{CO}$ & Smoking \\
\hline $\begin{array}{l}\text { North } \\
\text { Male }\end{array}$ & 0.083 & 0.070 & 0.093 & 0.036 & 0.083 & 0.065 & $0.143^{*}$ \\
$\quad \begin{array}{l}\text { Female } \\
\text { South }\end{array}$ & 0.153 & 0.034 & $0.154^{*}$ & 0.107 & 0.056 & 0.156 & - \\
Male & & & & & & & \\
Female & $0.243^{* *}$ & 0.210 & $0.140^{* *}$ & $0.199^{* *}$ & $0.314^{* *}$ & $0.230^{* *}$ & $0.129^{*}$ \\
\hline
\end{tabular}

Note: ${ }^{* *} 1 \%$ level of statistical significance; ${ }^{*} 5 \%$ level of statistical significance

For males in South China, the interaction between smoking and PM2.5 had the highest q value of 0.510 , which is greater than the sum of the $q$ values of each factor individually, indicating effect modification for the cancer. This was followed by the interaction between smoking and PM10, with a $\mathrm{q}$ value of 0.421 , and the interaction between PM2.5 and $\mathrm{O}_{3}$, showing a q value of 0.398. The dominant interaction in South China was between smoking and PM2.5.

\section{Discussion}

As one of the most common malignancies in China, lung cancer poses a great threat to the health of the
Chinese. Air pollution has been found to be a risk factor of lung cancer, whereas the spatial association between pollutants and lung cancer in China remains unclear. In this study, the influence of outdoor air pollution on lung cancer incidence in north and south China for different genders was analysed. These results indicated that the influence of air pollution on lung cancer presented apparent spatial and gender heterogeneities, and when smoking combined with air pollution, the risk of lung cancer greatly increased in males.

The consumption of coal in China has been higher than the global average. In 2013, the amount of coal use in China is about 2943 million tons, accounting for more

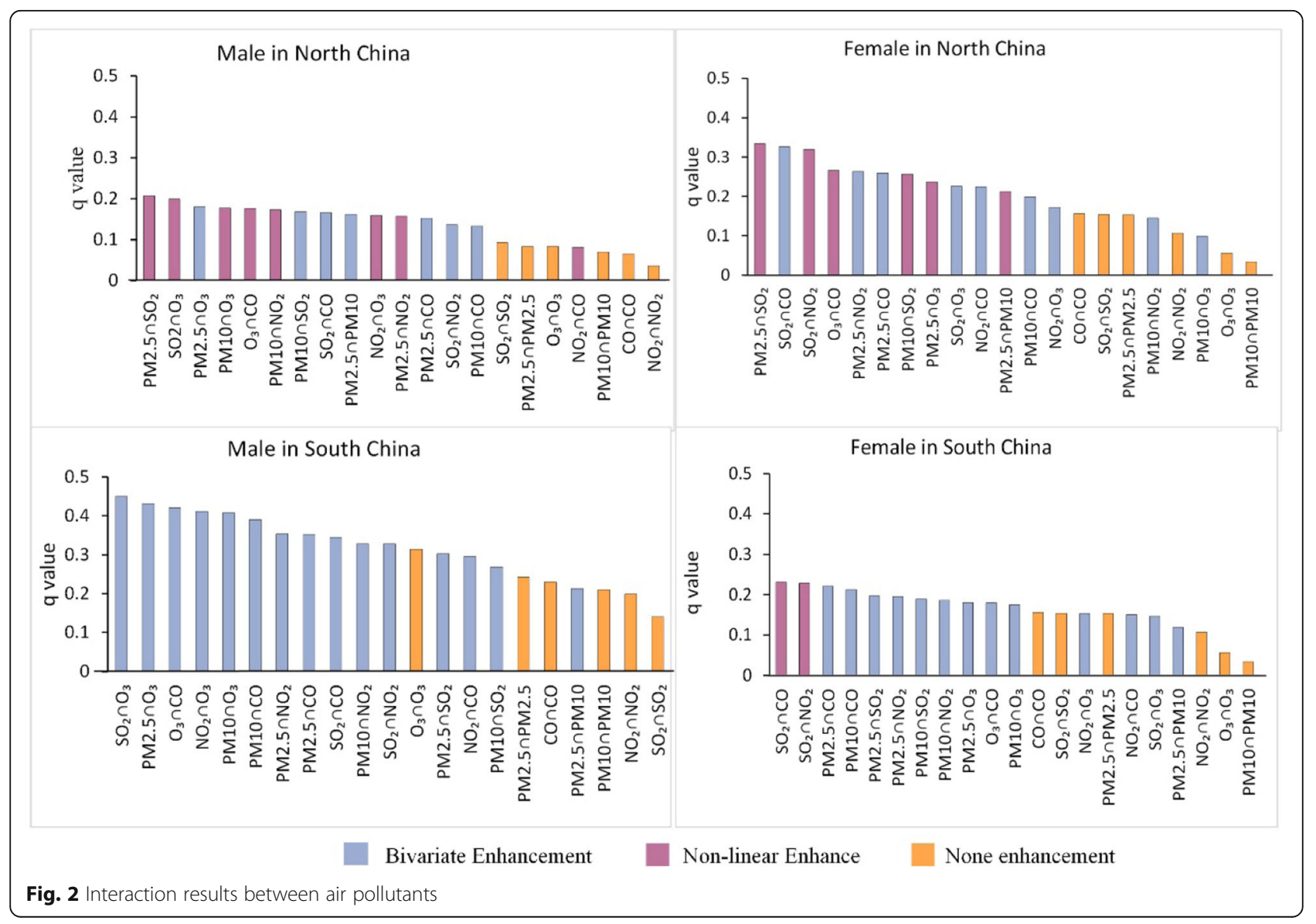




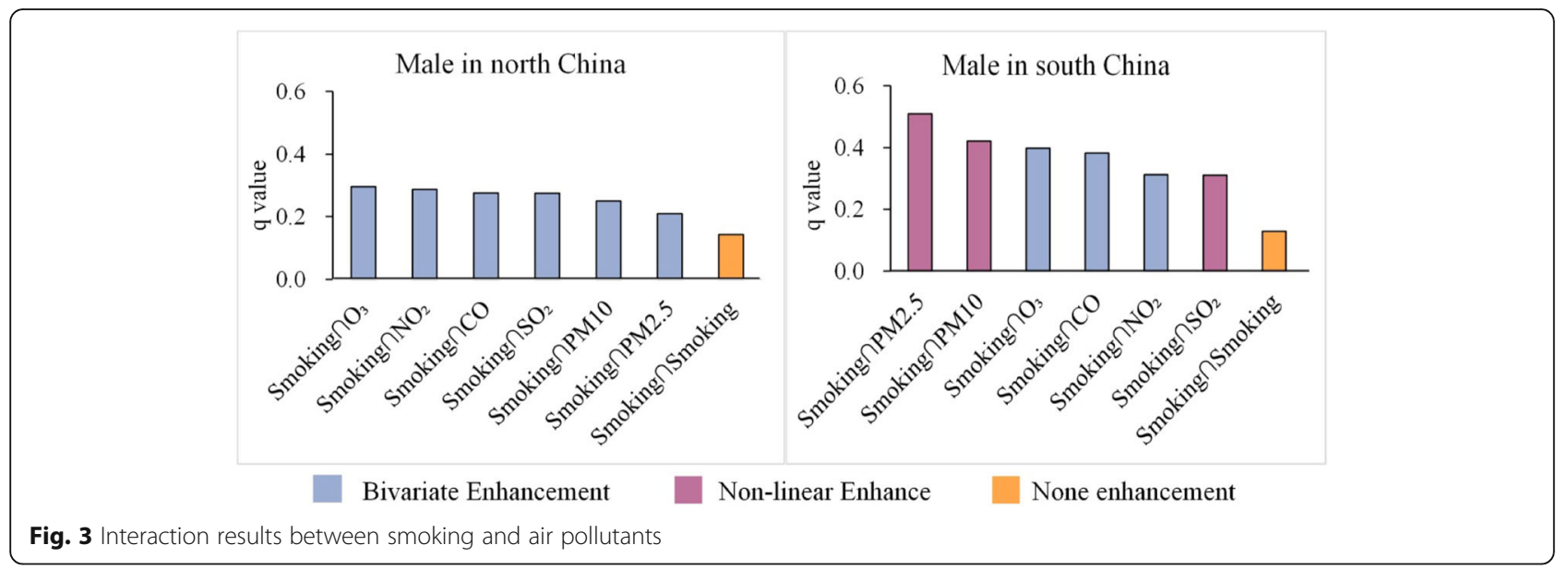

than half of global total [46]. As a product of coal combustion, $\mathrm{SO}_{2}$ is more harmful in China than are traffic-related pollutants, such as $\mathrm{NO}_{2}$ [47]. One study examined the association of $\mathrm{SO}_{2}$ and $\mathrm{NO}_{\mathrm{X}}$ with mortality in China and indicated that an increase of $10 \mu \mathrm{g} / \mathrm{m}^{3}$ of $\mathrm{SO}_{2}$ corresponded to a $4.2 \%$ (95\% CI: $2.3,6.2 \%)$ increase of lung cancer mortality, which was apparently higher than that of $\mathrm{NO}_{\mathrm{X}}(2.7 \%$ (95\% CI: - 0.9, 6.5\%)) [10].

In the current research, we found a larger impact of $\mathrm{SO}_{2}$ on lung cancer in the north compared with that in the south. This may be because the concentration of $\mathrm{SO}_{2}$ in northern China is obviously higher than that in the south. One study which analysis the spatial variation in 26 cities in China reported that the average concentration of $\mathrm{SO}_{2}$ in northern cities is $72 \mu \mathrm{g} / \mathrm{m}^{3}$, almost as twice as that of southern cities [24], and more than three times the standard concentration given by the World Health Organization (WHO) air quality guidelines, suggesting that the minimum health-hazard concentration for $\mathrm{SO}_{2}$ is less than $20 \mu \mathrm{g} / \mathrm{m}^{3}$. Exposure to high levels of $\mathrm{SO}_{2}$ increases the risk of lung cancer in northern populations.

PM2.5 has been widely examined for its effect on lung cancer. A study in China which examined the association between lung cancer incidence from 1999 to 2009 and PM2.5 found a statistically significant correlation with lung cancer and revealed that females had a slightly higher risk than did males [21]. However, few studies have analysed the effect of PM2.5 on lung cancer incidence in different regions of China. A work which explored the association between lung cancer mortality rate and PM2.5 in 31 provinces in China indicated that there were three northeastern provinces and some southern provinces that had positive correlations with lung cancer in males and females, respectively [48].

The chemical compositions of PM2.5 in China are mainly including organic matter, heavy metal, inorganic ion and trace inorganic non-metallic elements $[49,50]$. Yao [51] indicated that the dominant ionic species SO24 in PM2.5 might be formed through the direct emissions of $\mathrm{SO}_{2}$. Our study found the interaction between $\mathrm{SO}_{2}$ and PM2.5 can modify the risk of lung cancer, no matter in males or females in north China. This is consistent with the spatial distribution of PM2.5 in China. Previous studies reported the average concentration of PM2.5 in north China reached as high as $80-100 \mu \mathrm{g} / \mathrm{m}^{3}$, while in south, the concentration has reduced to $40-70 \mu \mathrm{g} / \mathrm{m}^{3}$ [52].

The health effects of ambient $\mathrm{O}_{3}$ and $\mathrm{CO}$ have been assessed recently. One study used 20 communities (10 each from southern and northern U.S.) using a generalised linear model to estimate the association between increments in $\mathrm{O}_{3}$ concentration and mortality in every community, and found that the effect of $\mathrm{O}_{3}$ on mortality was positively related to latitude [53]. A study in Taiwan found a significant correlation between $\mathrm{CO}$ and $\mathrm{O}_{3}$, and female lung cancer [35]. In our study, $\mathrm{CO}$ and $\mathrm{O}_{3}$ had a significant effect on lung cancer, but they showed substantial discrepancy in north and south China. They were more strongly association with lung cancer in the south.

Some previous studies have indicated local regional relationships between PM10 or $\mathrm{NO}_{2}$ and lung cancer. One study in New Hampshire, U.S., found a significant contribution of PM10 to lung cancer only in the northern and southwestern regions of the state; thus, PM10 did not completely explain the lung cancer incidence [54]. Another study from Saudi Arabia analysed the association between $\mathrm{NO}_{2}$ and the incidence of the most common cancers (including lung cancer) and found higher coefficients of determination in the Eastern, Riyadh and Makkah regions than in other areas [55]. These findings are consistent with current study, which also indicated geospatial heterogeneity in the influence of PM10 and $\mathrm{NO}_{2}$ on lung cancer. 
Meanwhile, our study found a stronger association between lung cancer and air pollution in males than in females in south China. This may be attributable to the fact that there is a high proportion of women suffering the risk of household pollution from such substances as pollutants emitted in the cooking of food [56]. Exposure to household pollution can pose a serious health hazard, particularly for women who spend much time inside of their house [57].

The potential biological mechanism behind the higher sensitivity of the south population than the north to outdoor air pollution might be that the north has a higher risk of household pollution [58], which is a top cause of death in China [14]. Household air pollution causes about 420,000 premature deaths annually, which is $40 \%$ more than that attributed to outdoor air pollution [59].

The combustion of solid fuels (biomass and coal) is the main source of household air pollution [59]. Approximately $72.5 \%$ of the population in the north uses solid fuels, which is $13 \%$ higher than that in the south. Compared with the winter temperature in the south, that in the north is lower, thus leading to prolonged heating times. This may be putting the north at risk of household air pollution. For example, a study which monitored three important indoor air pollutants $(\mathrm{CO}$ and respirable particles (RPM)) in four provinces during heating seasons in China reported that northern provinces have higher $\mathrm{CO}$ and RPM concentrations in rooms than do southern provinces [60].

The significant effects of smoking on lung cancer among men may be attributed to high prevalence of smoking in males. When smoking interacts with air pollutants-especially PM2.5 or $\mathrm{O}_{3}$-the risk of lung cancer increases significantly. This indicates that when air pollution and smoking work together, the likelihood of lung cancer shows non-linear growth, an issue that requires attention in both regions of China.

There were also some limitations in the study. First, the different time period of lung cancer and air pollution would introduce some uncertainties in the results. However, the long-term spatial relationship between air pollution and lung cancer is relatively stable and the influence on results would be rare in the Geodetector method due to the use of categorical data. As such, although the study did not analyse the effects of long-term exposure to air pollution on lung cancer, uncertainties will be diminished by using Geodetector method. Second, under-reporting or misdiagnosis of lung cancer datasets were not considered in this study. Although it may lead the misunderstanding results, this limitation can be attenuated by the examination of data for quality and integrity. Since the data was officially published by the National Cancer Center and reported under quality assurance procedures to guarantee its reliability, the possibility of under-reporting or misdiagnosis within the dataset is significantly reduced. Finally, since exposure to other pollutants such as airborne polycyclic aromatic hydrocarbons (PAHs) [61] or total suspended particle (TSP) [10] are also among the prominent causes of lung cancer, additional factors should be taken into account in future research.

\section{Conclusion}

In conclusion, this study found apparent spatial and gender heterogeneities in the association between air pollution and lung cancer. Air pollution in south China has a greater impact on lung cancer than that in the north; however, females in the north are more likely to be affected by polluted air than the males. In north China, the main risk factors is $\mathrm{SO}_{2}$, and the dominant interactive factor is that between $\mathrm{SO}_{2}$ and PM2.5. Meanwhile, in south China, the six selected pollutants in this study have different degrees of influence on lung cancer, and the dominant interactive factor are that between $\mathrm{SO}_{2}$ and $\mathrm{O}_{3}$ in males and between $\mathrm{SO}_{2}$ and $\mathrm{CO}$ in females.

\section{Abbreviations \\ $\mathrm{CO}$ : Carbon monoxide; $\mathrm{NO}_{2}$ : Nitrogen dioxide; $\mathrm{O}_{3}$ : Ozone; $\mathrm{PAHs}$ : Airborne polycyclic aromatic hydrocarbons; PM10: Inhalable particles; PM2.5: Fine particulate; $\mathrm{SO}_{2}$ : Sulfur dioxide; TSP: Total suspended particle}

\section{Acknowledgements}

Not applicable.

\section{Authors' contributions}

$X D F, X C D, L X Y$ conceived of the study and designed the study. XDF, XCD, HMG and WJX did the main analyses. XTY and CSP contributed to refining the ideas, carrying out additional analyses. All authors discussed the results and revised the manuscript. All authors read and approved the final manuscript.

\section{Funding}

This study was supported by the following grants: Strategic Priority Research Program of the Chinese Academy of Sciences (XDA19040302); National Natural Science Foundation of China (41601419, 41531179, 41601478); Innovation Project of LREIS (O88RA205YA, O88RA200YA); National Key R\&D Program of China (2017YFC1602002, 2017YFC1601801).

These funding bodies had no role in study design, collection or analysis/ interpretation of data; they also had no role in manuscript writing.

\section{Availability of data and materials}

The datasets used during the current study are publicly available. The lung cancer incidence data is available in the book: Jie He CW: Annual Report of Cancer Registration in China 2016. China: Tsinghua University Press; 2017, the air pollution data is available in http://106.37.208.233:20035/.

Ethics approval and consent to participate

Not applicable.

\section{Consent for publication}

Not applicable.

\section{Competing interests}

The authors declare they have no competing financial interests.

\section{Author details}

${ }^{1}$ State Key Laboratory of Resources and Environmental Information System, Institute of Geographic Sciences and Natural Resources Research, Chinese Academy of Sciences, Beijing, China. ${ }^{2}$ School of Information Engineering, 
China University of Geosciences, Beijing 100083, China. ${ }^{3}$ Key Laboratory of Land Surface Pattern and Simulation, Beijing Key Laboratory of Environmental Damage Assessment and Remediation, Institute of Geographic Sciences and Natural Resources Research, Chinese Academy of Science (CAS), Beijing 100101, China. ${ }^{4}$ Key Laboratory of Water and Sediment Sciences, Ministry of Education; Department of Environmental Engineering, Peking University, Beijing 100871, China.

\section{Received: 26 November 2018 Accepted: 4 October 2019} Published online: 26 October 2019

\section{References}

1. Torre LA, Bray F, Siegel RL, Ferlay J, Lortet-Tieulent J, Jemal A. Global Cancer statistics, 2012. CA-Cancer J Clin. 2015;65(2):87-108. https://doi.org/10.3322/ caac. 21262.

2. Siegel RL, Miller KD, Jemal A. Cancer statistics, 2017. CA-Cancer J Clin. 2017; 67(1):7-30. https://doi.org/10.3322/caac.21387.

3. Ridge CA, McErlean AM, Ginsberg MS. Epidemiology of lung Cancer. Semin Interv Radiol. 2013;30(2):93-8. https://doi.org/10.1055/s-0033-1342949.

4. Guo P, Huang ZL, Yu P, Li K. Trends in cancer mortality in China: an update. Ann Oncol. 2012;23(10):2755-62. https://doi.org/10.1093/annonc/mds069.

5. Chen W, Zhang S, Zou X. Estimation and projection of lung cancer incidence and mortality in China. Zhongguo Fei Ai Za Zhi. 2010;13(5):48893. https://doi.org/10.3779/j.issn.1009-3419.2010.05.20.

6. Chen WQ, Zheng RS, Baade PD, Zhang SW, Zeng HM, Bray F, Jemal A, Yu XQ, He J. Cancer statistics in China, 2015. CA-Cancer J Clin. 2016;66(2):11532. https://doi.org/10.3322/aac.2138.

7. Shi C L, Lou P A, Shi J, F, Huang H Yue: Systematic evaluation of the economic burden of lung cancer in China from 1996 to 2014. Public Health in China 2017, 33(12):1767-1774.

8. He YY, Li S, Ren SX, Cai WJ, Li XF, Zhao C, Li JY, Chen XX, Gao GH, Li W, et al. Impact of family history of cancer on the incidence of mutation in epidermal growth factor receptor gene in non-small cell lung cancer patients. Lung Cancer. 2013;81(2):162-6. https://doi.org/10.1016/j.lungcan. 2013.05.004.

9. Chen WQ, Xia CF, Zheng RS, Zhou MG, Lin CQ, Zeng HM, Zhang SW, Wang $L$, Yang ZX, Sun KX, et al. Disparities by province, age, and sex in sitespecific cancer burden attributable to 23 potentially modifiable risk factors in China: a comparative risk assessment. Lancet Glob Health. 2019;7(2):E25769. https://doi.org/10.1016/S2214-109X(18)30488-1.

10. Cao J, Yang CX, Li JX, Chen RJ, Chen BH, Gu DF, Kan HD. Association between long-term exposure to outdoor air pollution and mortality in China: a cohort study. J Hazard Mater. 2011;186(2-3):1594-600. https://doi. org/10.1016/j.jhazmat.2010.12.036.

11. Cohen AJ. Outdoor air pollution and lung cancer. Environ Health Perspect. 2000;108:743-50. https://doi.org/10.1289/ehp.00108s4743.

12. Chan CK, Yao X. Air pollution in mega cities in China. Atmos Environ. 2008; 42(1):1-42.

13. Kan HD, Chen BH, Hong CJ. Health impact of outdoor air pollution in China: current knowledge and future research needs. Environ Health Perspect. 2009;117(5):A187. https://doi.org/10.1016/j.atmosenv.2007.09.003.

14. Yang GH, Wang Y, Zeng YX, Gao GF, Liang XF, Zhou MG, Wan X, Yu SC, Jiang YH, Naghavi M, et al. Rapid health transition in China, 1990-2010: findings from the global burden of disease study 2010. Lancet. 2013; 381(9882):1987-2015. https://doi.org/10.1016/S0140-6736(13)61097-1.

15. Song CB, He JJ, Wu L, Jin TS, Chen X, Li RP, Ren PP, Zhang L, Mao HJ. Health burden attributable to ambient PM2.5 in China. Environ Pollut. 2017; 223:575-86. https://doi.org/10.1016/j.envpol.2017.04.075.

16. Guo YM, Zeng HM, Zheng RS, Li SS, Pereira G, Liu QY, Chen WQ, Huxley R. The burden of lung cancermortality attributable to fine particles in China. Sci Total Environ. 2017;579:1460-6. https://doi.org/10.1016/j.scitotenv.2016. 11.147.

17. Liu J, Han YQ, Tang X, Zhu J, Zhu T. Estimating adult mortality attributable to PM2.5 exposure in China with assimilated PM2.5 concentrations based on a ground monitoring network. Sci Total Environ. 2016;568:1253-62. https://doi.org/10.1016/j.scitotenv.2016.05.165.

18. Raaschou-Nielsen O, Andersen ZJ, Beelen R, Samoli E, Stafoggia M, Weinmayr G, Hoffmann B, Fischer P, Nieuwenhuijsen MJ, Brunekreef B et al: Air pollution and lung cancer incidence in 17 European cohorts: prospective analyses from the European study of cohorts for air pollution effects (ESCAPE). Lancet Oncol 2013, 14(9):813-822. https://doi.org/10.1016/ S1470-2045(13)70279-1.

19. Turner MC, Krewski D, Pope CA, Chen Y, Gapstur SM, Thun MJ: Long-term ambient fine particulate matter air pollution and lung Cancer in a large cohort of never-smokers. Am J Respir Crit Care Med 2011, 184(12):13741381. 13741381.https://doi.org/10.1164/rccm.201106-10110C

20. Atkinson RW, Butland BK, Dimitroulopoulou C, Heal MR, Stedman JR, Carslaw N, Jarvis D, Heaviside C, Vardoulakis S, Walton H, et al. Long-term exposure to ambient ozone and mortality: a quantitative systematic review and meta-analysis of evidence from cohort studies. BMJ Open. 2016;6(2):10. https://doi.org/10.1136/bmjopen-2015-009493.

21. Guo YM, Zeng HM, Zheng RS, Li SS, Barnett AG, Zhang SW, Zou XN, Huxley $\mathrm{R}$, Chen WQ, Williams $\mathrm{G}$. The association between lung cancer incidence and ambient air pollution in China: a spatiotemporal analysis. Environ Res. 2016;144:60-5. https://doi.org/10.1016/j.envres.2015.11.004.

22. Katsouyanni K. Ambient air pollution and health. Br Med Bull. 2003;68:14356. https://doi.org/10.1093/bmb/ldg028.

23. Song CB, Wu L, Xie YC, He J, Chen X, Wang T, Lin YC, Jin TS, Wang AX, Liu $Y$, et al. Air pollution in China: status and spatiotemporal variations. Environ Pollut. 2017;227:334-47. https://doi.org/10.1016/j.envpol.2017.01.060.

24. Chai FH, Gao J, Chen ZX, Wang SL, Zhang YC, Zhang JQ, Zhang HF, Yun YR, Ren C. Spatial and temporal variation of particulate matter and gaseous pollutants in 26 cities in China. J Environ Sci. 2014;26(1):75-82. https://doi. org/10.1016/S1001-0742(13)60383-6.

25. Wang JF, Li XH, Christakos G, Liao YL, Zhang T, Gu X, Zheng XY. Geographical detectors-based health risk assessment and its application in the neural tube defects study of the Heshun region, China. Int J Geogr Inf Sci. 2010;24(1):107-27. https://doi.org/10.1080/13658810802443457.

26. Jie He CW. Annual report of Cancer registration in China 2016. China: Tsinghua University Press; 2017.

27. Zhou Q, Bian J, Zheng J. Variation of air temperature and thermal resources in the northern and southern regions of the Qinling Mountains from 1951 to 2009. Acta Geograph Sin. 2011;66(9):1211-8.

28. She J, Yang P, Hong QY, Bai CX. Lung Cancer in China challenges and interventions. Chest. 2013;143(4):1117-26. https://doi.org/10.1378/chest.112948.

29. Valavanidis A, Vlachogianni T, Fiotakis K, Loridas S. Pulmonary oxidative stress, inflammation and Cancer: Respirable particulate matter, fibrous dusts and ozone as major causes of lung carcinogenesis through reactive oxygen species mechanisms. Int J Environ Res Public Health. 2013;10(9):3886-907. https://doi.org/10.3390/ijerph10093886.

30. Hamra GB, Guha N, Cohen A, Laden F, Raaschou-Nielsen O, Samet JM, Vineis $P$, Forastiere $F$, Saldiva $P$, Yorifuji T, et al. Outdoor particulate matter exposure and lung Cancer: a systematic review and meta-analysis. Environ Health Perspect. 2014;122(9):906-11. https://doi.org/10.1289/ehp/1408092.

31. Wang N, Mengersen K, Kimlin M, Zhou MG, Tong SL, Fang LW, Wang BH, Hu WB. Lung cancer and particulate pollution: a critical review of spatial and temporal analysis evidence. Environ Res. 2018;164:585-96. https://doi. org/10.1016/j.envres.2018.03.034.

32. Chen S, Li YR, Yao Q. The health costs of the industrial leap forward in China: evidence from the sulfur dioxide emissions of coal-fired power stations. China Econ Rev. 2018;49:68-83. https://doi.org/10.1016/j.chieco. 2018.01.004.

33. Faridi S, Shamsipour M, Krzyzanowski M, Kunzli N, Amini H, Azimi F, Malkawi M, Momeniha F, Gholampour A, Hassanvand MS, et al. Long-term trends and health impact of PM2.5 and O-3 in Tehran, Iran, 2006-2015. Environ Int. 2018;114:37-49. https://doi.org/10.1016/j.envint.2018.02.026.

34. Jerrett M, Burnett RT, Beckerman BS, Turner MC, Krewski D, Thurston G, Martin RV, van Donkelaar A, Hughes E, Shi YL, et al. Spatial analysis of ai pollution and mortality in California. Am J Respir Crit Care Med. 2013;188(5): 593-9. https://doi.org/10.1164/rccm.201303-06090C.

35. Liaw YP, Ting TF, Ho KK, Yang CF. Cell type specificity of lung cancer associated with air pollution. Sci Total Environ. 2008;395(1):23-7. https://doi. org/10.1016/j.scitotenv.2008.01.053.

36. Yang WS, Zhao H, Wang X, Deng Q, Fan WY, Wang L. An evidence-based assessment for the association between long-term exposure to outdoor air pollution and the risk of lung cancer. Eur J Cancer Prev. 2016;25(3):163-72. https://doi.org/10.1097/CEJ.0000000000000158.

37. Hystad P, Demers PA, Johnson KC, Carpiano RM, Brauer M. Long-term residential exposure to air pollution and lung Cancer risk. Epidemiology. 2013;24(5):762-72. https://doi.org/10.1097/ede.0b013e3182949ae7. 
38. Wang MH, Luo X, Xu SB, Liu WH, Ding FF, Zhang XX, Wang L, Liu J, Hu JP, Wang W: Trends in smoking prevalence and implication for chronic diseases in China: serial national cross-sectional surveys from 2003 to 2013. Lancet Resp Med 2019, 7(1):35-45. https://doi.org/10.1016/S22132600(18)30432-6.

39. Goovaerts P. Geostatistical analysis of disease data: visualization and propagation of spatial uncertainty in cancer mortality risk using Poisson kriging and p-field simulation. Int J Health Geogr. 2006;5(1):7. https://doi. org/10.1186/1476-072X-5-7.

40. Goovaerts P. Geostatistical analysis of disease data: accounting for spatial support and population density in the isopleth mapping of cancer mortality risk using area-to-point Poisson kriging. Int J Health Geogr. 2006;5:52. https://doi.org/10.1186/1476-072X-5-52.

41. Goovaerts P. Kriging and semivariogram deconvolution in the presence of irregular geographical units. Math Geosci. 2008;40(1):101-28. https://doi.org/ 10.1007/s11004-007-9129-1.

42. Wang JF, Zhang TL, Fu BJ. A measure of spatial stratified heterogeneity. Ecol Indic. 2016;67:250-6. https://doi.org/10.1016/j.ecolind.2016.02.052.

43. Wang J, Xu C. Geodetector: principle and prospective. Acta Geograph Sin. 2017;72(1):116-34.

44. Wang JF, Xu CD, Hu MG, Li QX, Yan ZW, Jones P. Global land surface air temperature dynamics since 1880. Int J Climatol. 2018;38:E466-74. https:// doi.org/10.1002/joc.5384

45. Luo W, Liu CC. Innovative landslide susceptibility mapping supported by geomorphon and geographical detector methods. Landslides. 2018;15(3): 465-74. https://doi.org/10.1007/s10346-017-0893-9.

46. Yuan JH. The future of coal in China. Resour Conserv Recycl. 2018;129:290-2.

47. Finkelman RB, Tian LW. The health impacts of coal use in China. Int Geol Rev. 2018;60(5-6):579-89. https://doi.org/10.1080/00206814.2017.1335624.

48. Fu JY, Jiang D, Lin G, Liu K, Wang Q. An ecological analysis of PM2.5 concentrations and lung cancer mortality rates in China. BMJ Open. 2015; 5(11):9. https://doi.org/10.1136/bmjopen-2015-009452.

49. Wang $Y$, Zhuang GS, Tang AH, Yuan H, Sun YL, Chen SA, Zheng AH. The ion chemistry and the source of PM2.5 aerosol in Beijing. Atmos Environ. 2005; 39(21):3771-84.

50. Wang Y, Zhuang GS, Zhang XY, Huang K, Xu C, Tang AH, Chen JM, An ZS. The ion chemistry, seasonal cycle, and sources of PM2.5 and TSP aerosol in Shanghai. Atmos Environ. 2006;40(16):2935-52. https://doi.org/10.1016/j. atmosenv.2005.03.013.

51. Yao XH, Chan CK, Fang M, Cadle S, Chan T, Mulawa P, He KB, Ye BM. The water-soluble ionic composition of PM2.5 in Shanghai and Beijing, China. Atmos Environ. 2002;36(26):4223-34. https://doi.org/10.1016/S13522310(02)00342-4

52. Wang S, Hao J. Air quality management in China: issues, challenges, and options. J Environ Sci. 2012;24(1):2-13. https://doi.org/10.1016/S10010742(11)60724-9.

53. Liu T, Zeng WL, Lin HL, Rutherford S, Xiao JP, Li X, Li ZH, Qian ZM, Feng BX, Ma WJ. Tempo-spatial variations of ambient ozone-mortality associations in the USA: results from the NMMAPS data. Int J Environ Res Public Health. 2016;13(9):14. https://doi.org/10.3390/ijerph13090851.

54. Sloan CD, Andrew AS, Gruber JF, Mwenda KM, Moore JH, Onega T, Karagas MR, Shi X, Duell EJ. Indoor and outdoor air pollution and lung cancer in New Hampshire and Vermont. Toxicol Environ Chem. 2012;94(3):605-15. https://doi.org/10.1080/02772248.2012.659930.

55. Al-Ahmadi K, Al-Zahrani A. NO2 and Cancer incidence in Saudi Arabia. Int J Environ Res Public Health. 2013;10(11):5844-62. https://doi.org/10.3390/ ijerph10115844.

56. Ko YC, Cheng LSC, Lee CH, Huang JJ, Huang MS, Kao EL, Wang HZ, Lin HJ. Chinese food cooking and lung cancer in women nonsmokers. Am J Epidemiol. 2000;151(2):140-7. https://doi.org/10.1093/oxfordjournals.aje.a010181.

57. Baumgartner J, Schauer JJ, Ezzati M, Lu L, Cheng C, Patz J, Bautista LE. Patterns and predictors of personal exposure to indoor air pollution from biomass combustion among women and children in rural China. Indoor Air. 2011;21(6):479-88. https://doi.org/10.1111/j.16000668.2011.00730.x.

58. Mestl HES, Aunan K, Seip HM, Wang S, Zhao Y, Zhang D. Urban and rural exposure to indoor air pollution from domestic biomass and coal burning across China. Sci Total Environ. 2007;377(1):12-26. https://doi.org/10.1016/j. scitotenv.2007.01.087.

59. Zhang JJ, Smith KR. Household air pollution from coal and biomass fuels in China: measurements, health impacts, and interventions. Environ Health Perspect. 2007;115(6):848-55. https://doi.org/10.1289/ehp.9479.
60. Jin YL, Zhou Z, He GL, Wei HZ, Liu J, Liu F, Tang N, Ying B, Liu YC, Hu GH, et al. Geographical, spatial, and temporal distributions of multiple indoor air pollutants in four Chinese provinces. Environ Sci Technol. 2005;39(24):94319. https://doi.org/10.1021/es0507517.

61. Kim KH, Jahan SA, Kabir E, Brown RJC. A review of airborne polycyclic aromatic hydrocarbons (PAHs) and their human health effects. Environ Int. 2013;60:71-80. https://doi.org/10.1016/j.envint.2013.07.019.

\section{Publisher's Note}

Springer Nature remains neutral with regard to jurisdictional claims in published maps and institutional affiliations.

\section{Ready to submit your research? Choose BMC and benefit from:}

- fast, convenient online submission

- thorough peer review by experienced researchers in your field

- rapid publication on acceptance

- support for research data, including large and complex data types

- gold Open Access which fosters wider collaboration and increased citations

- maximum visibility for your research: over $100 \mathrm{M}$ website views per year

At BMC, research is always in progress.

Learn more biomedcentral.com/submissions 